\title{
Communicated Accountability Of Charitable Organisations: The Case Of Nigeria
}

\author{
Mubarak Shehu Musawa* \\ Hassan Usman Katsina Polytechnic, Nigeria
}

\begin{abstract}
The aim of this study is to examine how accountability is practised by charity institutions in Nigeria.The paper employs Ebrahim's charity accountability framework to analyse BudgIT's website, public related documents and news. It is observed that the practice of accountability by BudgIT lays emphasis on upward accountability to donors, focused on primarily reporting basic descriptive financial and performance information. However the research is based on a content analysis of a single charity organisation and, therefore, any generalising of the conclusions beyond BudgIT may not represent the reporting behaviour of all charity institutions in Nigeria.This paper is among the few studies that investigate the reporting behaviour of charitable institutions in a developing country, thus contributing to the scanty literature on charitable accountability in Nigeria.
\end{abstract}

JEL: D90, M40.

Keywords : reporting behaviour; accountability; charity; Nigeria.

\section{INTRODUCTION}

In recent decades, charity organisations have experienced tremendous growth due to several factors among which are being significant players in the social welfare development of the disadvantaged and an active catalyst for social change (Baur \& Schmitz, 2012; Connolly, 2012; Dhanani \& Connolly, 2012; Ebrahim, 2003a, 2003b; Edun, 2000; Goddard \& Assad, 2006; Hooper et al., 2007). Nonetheless, public confidence and trust in these institutions have eroded in recent times due tore-occurrences of scandals, misappropriation of resources, bad governance, organisational inefficiency and even terrorist financing (Ebrahim, 2003b; Dellaportas et al., 2012; Dunne, 2013; O’Dwyer \& Boomsma, 2015; Yasmin et al., 2014), hence raising the need for greater public scrutiny of the sector (Connolly \& Hyndman, 2013; Dellaportas, Langton, \& West, 2012; O'Dwyer \& Unerman, 2007, 2008).

A wide spectrum of studieshas been carried out globally to determine the accountability of the charity sector empirically. However, in sub-Sahara Africa, specifically Nigeria, academic research on the accountability of the third sector is under-explored. Hence this paper fills this lacuna in the literature. While there are several accountability aspects to study in the Nigerian charity sector, this paper evaluates the reporting behaviour of the charity organisation, BudgIT. BudgIT is a civic organisationselected as the case studybecause its mandate isto promote transparency and accountability in governments by enlightening Nigerians onfiscal information.

\footnotetext{
*Email : mubarakshehumusawa@gmail.com

Received : 01-02-2019, Accepted : 06-02-2019, Published : 29-04-2019

P-ISSN : 2087 -9954, E-ISSN : 2550 - 0066. DOI : http://dx.doi.org/10.26418/jebik.v8vi1.31157
} 
Consequently, accountability, which is the core philosophy of BudgIT, is assumed to simultaneously reflect in their scope of work. Yet no published study has revealed what type of accountability behaviour is practised in BudgIT. This paper endeavours to rectify this oversight.

To achieve the study objective, the accountability mechanism developed by Ebrahim (2003a, 2003b, 2010) will be employed to examine the communicated accountability of BudgIT. The primary key motivation for conducting this study is the lack of published accountability literature on the charity sector in Nigeria despite the growing economic influence of the sector in the country (Odumosu, Olaniyi, \& Alonge, 2009). The format of the remaining paper is arranged as follows. The paper reviews prior literature on the reporting behaviour of charitable institutions. Thisis followed by detailing the research methodology used for the study. The next section examines and discusses the results of the analysis before drawing to conclusions in the final section.

\section{LITERATURE REVIEW}

Definition of Charity

Before discussing the issue at hand, a caveat must be put to record relating to the attempt to describe an entity as a charitable organisation. This is due to the fact that the literature contains numerous terminologies used to identify this sector. For example, terms like NGOs, Not-forprofit Organisations (NFPOs), Civil Society Organisations (CSOs), Third sector and Philanthropic trust are found. Hence, defining what constitutes a charitable institution would help ensure the correct focus of the discussion.

Charitable institutions are organisations set up not to profit the donors, but to further the social objectivesbehind the provision of goods and services for the benefit of marginalised communities (Andrews, 2014). Donors do not directly benefit from their donations. Rather, such contributions go to third parties which are the beneficiaries and the community at large (Collison et al., 2006; Connolly \& Hyndman, 2013).From the abovedescription of charitable organisations, studies (see Dellaportas et al., 2012; Dhanani \& Connolly, 2012; Hooper et al., 2007) have concluded that the charity sector is a subclass of NFPOs. According to Hooper et al. (2007), NFPOs are established with the sole aim to cater for the "disadvantaged members of the society" and not to pursue financial goals. This is the same mission of the charity sector. Interestingly, some literature also argued that NFPOs performed the same functions as NGOs and concluded that the term NFPOs could be used interchangeably (Andrews, 2014; Collison et al., 2006; Ebrahim, 2003, 2005).Similarly, Dellaportas et al. (2012) argued that the NFPOsare globally referred to as the 'third sector'.

This trend is observable in articlesconcerning the Nigerian charity sector. They refer to the use of the charity organisation interchangeably with either CSOs, third sector, NGOs or NFPOs (Bradely, 2005; Davis, Jegede, Leurs, Sunmola, \& Ukiwo, 2011; Essia \& Yearoo, 2009; Fasakin, 2011; Ibeanu, 2009; Nwokoro, 2017). Thus, in this paper, the literature concerning the reporting practices of charitable institutions, NFP organisations, third sector, CSO and NGO is drawn upon to deliberate the problem at hand. 


\section{Charity and Accountability}

The characteristics of a typical charity organisation encompass a broad range of important stakeholders (Andrews, 2014; Ebrahim, 2003b, 2004, 2005; Goddard \& Assad, 2006; Yasmin et al., 2014), with the stakeholders having different levels of influence and demand on the charity institutions (Robert Lloyd, 2005). These stakeholders include but are not limited to the donors (individuals or corporate organisations) whose donations are the primary source of funds to charity institutions; the beneficiaries/clients or communitiesas the recipients of the services provided by the charity sector; the government/regulatory body which provides legal framework and performs the oversight functions;and the staff (directors and employees) and volunteers who operationalise the mission of the charitable institutions. At the end of the day, the charity institutions are expected to be accountable to these multiple partiesby reporting informationvia formal communication channels (Connolly \& Hyndman, 2013; Ebrahim, 2010; Lloyd, 2005), despite the multiple parties having diverse accountability demands (Dhanani \& Connolly, 2012; Kaldor, 2003).

Accordingly, the charity institutions are expected to disclose their financial position and performance, utilisation of resources, achievement, programmes, policies and procedures and structure of the organisation (Connolly \& Hyndman, 2004; Yasmin et al., 2014). Arguably, to put in practice an equitable reporting and disclosure practice satisfying the above-stated actors is difficult (Ebrahim, 2010; O'Dwyer \& Boomsma, 2015). Either the reporting practice is oriented towards the conditions set by the donors, patrons and government, which is termed upward accountability or is somewhat accountable to the beneficiaries/clients, which is known as downward accountability or being accountable to the mission, staff, decision-makers and field implementers of NGOs. This is referred to as internal accountability (Ebrahim, 2003a, 2003b, 2005, 2010).

Upward accountability simply means the reporting practice to a set of stakeholders (donors, government and patrons) who have a significantinfluence on the access and utilisation of funds of the charity organisation (Andrews, 2014; Ebrahim, 2003b; Lloyd, 2005). The primary purpose of this type of accountability is to meet the donors' need to understand how their donations were utilised (Jacobs \& Wilford, 2010). Osman (2012) stated that this kind of accountability is similar to corporate accountability (accountability to shareholders), i.e. being accountable to the parties who provided the funds. It is also referred to as hierarchical or functional accountability as itfocuses on being accountable to powerful stakeholders, who to some extent can determine the progress of institutions (Ciaran Connolly \& Hyndman, 2013; Brendan O'Dwyer \& Unerman, 2008; Unerman \& O'Dwyer, 2006). In a nutshell, accountability in an upward reporting personifies complying with accounting mechanisms set by the regulatory body and donors (Ebrahim, 2003b; Osman, 2012). Hence, such accountabilityis constantlycentred on the resource use (financial report), result and performance of institutions (progress report) (O’Dwyer \& Boomsma, 2015).

The effect of upward reporting lies in the notion of trying to provide quick andgood result and performance of the 'accountee'(Baur \& Schmitz, 2012).This, however, leads to anxiety and vulnerability on the part of the 'accountor'. Hence, the long-term strategic decisions of charity institutionsare shortchanged for immediate short-term results or short-term functional 
accountability, which in the long run is counterproductive, unsustainable and detrimental to the overall objective of the charity sector(Andrews, 2014; O'Dwyer \& Unerman, 2008; O'Dwyer \& Boomsma, 2015; Osman, 2012).Such a dysfunctional effect of upward accountability via an emphasis on resource use and immediate impact/physical achievement was aptly pointed out by Jacobs \& Wilford (2010: 4) that:

"the Tsunami Evaluation Coalition's report described instances of houses built that local people would never live in, the result of NGOs focusing on completing activities without fully understanding local peoples' priorities".

On the other hand, downward accountability or bottom-up means reporting tothe stakeholders for whom the institutions wereprincipally established (Ebrahim, 2010). In the case of the third sector, such stakeholders include the beneficiaries and the communities indirectly affected by the organisation's activities (Ebrahim, 2005). This type of reporting practice, unlike the hierarchical, is not determined by the 'accountees' as they lack the power to do so (Collison et al., 2006; Robert Lloyd, 2005). Rather, it emanates from the informal close relationship with the clients (Ahmad Zamri Osman, 2012). The inclusion of these 'accountees' in the reporting mechanisms tends to help charitable organisations to get feedback in the form of corrections, advice and guidance in the discharge of their primary objective (Ebrahim, 2003a). The resulting effect would be the prioritisation of charity institution's programmes and projects so as to address the needs and aspirations of the intended beneficiaries (Brendan O'Dwyer \& Unerman, 2008).However, since such accountability emanates as a result of moral and ethical obligation, such informal contract offers a scope for choice to the 'accountor' (Robert Lloyd, 2005). Thus, there is no standard format on how to be accountable to the downward parties which leads to variation in downward reporting among charitable institutions (Ebrahim, 2004).

\section{The Conflict between Upward and Downward Accountability}

Evidence from practiceshas shown that in trying to meet with therigorous standards set by the donors and regulators, there is a high tendency for the NGOs to neglect the downward stakeholder. Implicit in this discourse is several studies by Ebrahim (2003a, 2003b, 2004, 2005, 2010) in which, among others, the author revealedthat NGOs' accountability in practice have upheld upward accountability and failed to develop accountability to the beneficiaries of the NGOs' services. Similarly, O'Dwyer (2005) study on a foreign aid agency concluded that the NGO would uphold upward accountability to maintain legitimacy in the eyes of its donors. Furthermore, O'Dwyer \& Unerman (2008) investigated Irish Amnesty International in order to assess the development of accountability in specific NGO contexts. The result of the study corroborated the findings of previous studies.

Even faith-based NGOs were found to be practising upward accountability. Yasmin et al. (2014) used the famous Stewart's (1984) "ladder of accountability" to determine accountability reporting practices of Muslim and Christian based charities in the UK. The study found that both faith-based organisations' accountability mechanismislimited to the disclosure of financial figures without incorporating performance achievement. This typically represents probity and compliance to a set of standards, indicatinghierarchical accountability (Baur \& Schmitz, 2012; Alnoor Ebrahim, 2010). Also, the study by Andrews (2014) on 77 NGOs that participated in the Zapatista movement in Mexico found that 24 of the NGOs abandoned the Zapatista solidarity 
because of the clash between the NGOs donors' demand for reporting and the Zapatista's demand to influence the NGOs' programmes. The study by Andrews (2014) thus illustrates how NGOs cannot sacrifice hierarchical accountability for downward accountability.

In Africa, studies also point to the dominance of upward accountability practice by NGOs. The study by Burger \& Seabe (2014) gave an overall summary of the NGOs' accountability in Africa. Their findings showed that even though there has been advocacy for new ways of instilling accountability between NGOs and community beneficiaries, there is little evidence to suggest that the dominant models of accountability have been successful in promoting downward accountability.

More specifically in South Sudan, Beattie (2011), through interviews and focus group discussions with NGOs and community beneficiaries, examined NGOs' downward accountability and found that downward accountability cannot be practised within certain contexts due to inherent structural difficulties. Bawole \& Langnel (2016) also examined NGOs' downward accountability in community project planning in Ghana. Employing the same research methodology of Beattie (2011) with NGOs, government officials and community members, the findings reveal that community members were engaged in project planning processes; however, these engagements were limited to endorsing pre-prepared plans, decisions, and insignificantaspects of the project. Hence, the authors concluded that downward accountability was found to be missing because the engagements were largely rhetorical and to gain legitimacy.

The theory of resource dependence has been used to explain the dominance of upward reporting (Andrews, 2014; Ebrahim, 2005; O’Dwyer \& Unerman, 2007). These studies suggest that when an organisation depends on another organisation for resources, the latter has more leverage to control the agenda. In the case of an NGO faced with various competing demands from stakeholders, "NGOs are likely to favour those who have the power to implement rewards and punishments" (Andrews, 2014 : 100). Apart from resource dependence, evidence also submits that such dominance could be due to other factors. For instance, a report by Ebrahim(2004) indicated that the mechanisms used by NGOs for downward accountability are poorly established. Also, Keystone (2006) pointed to the complexities and cost of resources as a major bottleneck of being accountable to beneficiaries. While the study by O'Dwyer \& Unerman (2007) highlighted that due to lack of resources, expertise and commitment, downward accountability could notbe practised. Furthermore,Baur \& Schmitz (2012) argued that the factors undermining the struggle for downward accountability in NGOs are twofold, namely organisational survival \& competition for donations and the increase in demand for more accountability on NGOs. Andrews (2014) also concurred with the findings of Baur and Schmitz, where he concluded that the monitoring and appraisal mechanisms put in place by the government and donors to ensure accountabilitymight neglect not only the downward stakeholders but also the core values of the NGOs.

To summarise the argument, prior literatureconcluded that accountability to donors and government in the third sector is most prevalent due to several factors but principally because of dependence on resources and legal recognition. However, evidence from Nigeria is yet to be established on what type of reporting behaviour is being practised by the third sector. This research is carried out to fill this lacuna in the literature by carrying out a content analysis of 
BudgIT's websites, publications and any related news. After describing the Nigerian charity sector in the next section, the research methodology is explained in detail.

\section{The Nigerian Charity Sector}

Although the statutory regulation in Nigeria did not explicitly define a charity organisation, the description of 'Companies Limited by Guarantee' under the Companies and Allied Matters Act (CAMA) (Republic of Nigeria, 1990) as amended covertly states what charity institutions entail. Section 26 (1) of CAMA states that:

"Where a company is to be formed for promoting commerce, art, science, religion, sports, culture, education, research, charity or other similar objects, and the income and property of the company are to be applied solely towards the promotion of its objects and no portion thereof is to be paid or transferred directly or indirectly to the members of the company except as permitted by this Act, the company shall not be registered as a company limited by shares, but may be registered as a company limited by guarantee".

CAMA further states that:

"A company limited by Guarantee is one that is incorporated primarily to promote the objective of such a company with its shareholders barred from distributing its profits among its members, as dividend or otherwise. In practice, companies limited by guarantee are registered in Nigeria to undertake strictly charitable objectives. In the event of the dissolution or winding up of a company limited by guarantee, its assets, after the liquidation of its liabilities, cannot also be distributed to its shareholders; instead, such profits must be transferred to another charitable organisation with objective similar to that of the company that is been dissolved".

The above definition defines and regulates charity institutions in Nigeria. In Nigeria, quantitative data is difficult to come by, but there are indications that the third sector is among the fastest growing sectors in the country (Essia \& Yearoo, 2009). According to Iheme (2001), there is no reliable, authentic register of charity organisations in the country because some charity organisation, even though big and vibrant, may not be registered with the Corporate Affairs Commission (CAC), an organ of the Federal Ministry of Internal Affairs. Studies have shown that as of 1987, there was only one (1) registered charity organisation in the country. However, currently, there are over a thousand registered charities (Davis et al., 2011; Essia \& Yearoo, 2009; Fasakin, 2011; Nwokoro, 2017).

Charity organisations are regulated by CAC in pursuant of CAMA. They are required by this legislative framework to submit annual returns each year to CAC (Section $370 \& 690$ CAMA). With regards to accounting and accountability, no specific statutory provisions state the rules of external reporting. However, as an accounting practice, charity organisations report on the basis of fund accounting (Iheme, 2001). In 2011, to improve the quality and consistency of information in NFPOs' financial statement, the Financial Reporting Council (FRC) of Nigeria issued the Statement of Accounting Standards 32 titled "Accounting by Not-for-profit organisations" (Asien, 2016). The financial statements of NFPOs according to the standard 
should include the following statement; 'accounting policies', 'financial position', 'activities', 'changes in net asset', 'cash flow' and 'notes to the account'. The essence of introducing this standard is not to only improve the quality and consistency of information in NFPOs financial statement, but also promote trust, confidence and enhance sector accountability (Asien, 2016).

\section{RESEARCH METHODOLOGY}

This study employs content analysis via the accounting mechanism developed by Ebrahim (2003a, 2003b, 2010). The accounting mechanism was specifically adopted to assess the three aspects of reporting behaviour; how can BudgIT be accountable? To whom are BudgIT accountable? and for what purpose will they be accountable? (see summary in table 1.1). BudgIT is a civic organisation established in 2011 that applies information technology (e.g. infographics) to promote citizen awareness by providing authentic and reliable data on government budget preparation and implementation. The process of educatingis donebyeducating citizens with information on public finance and fiscal analysis so that citizens will use such information to demand transparency and accountabilityat all levels of government (BudgIT's annual report, 2016). The reason for choosing this organisationis the philosophy in which BudgIT was established, namely accountability. However, no established evidence reveals the kind of accountability practised by the organisation to its stakeholders. Secondly, the website of BudgIT is functional and up to date.

Due to the nature of BudgIT, i.e. advocacy for transparency in public finance, it can be categorised under theNGO typology because of the following reasons espoused by Ebrahim (2003b, 2010) :

i. Their client/beneficiaries were not involved in creating BudgIT.

ii. The client/beneficiaries are external actors and have less influence in determining the activities of BudgIT.

iii. They have attracted other organisations by virtue of their mission; advocacy for accountability and transparency of public officials and elected policymakers.

iv. The mechanism of accountability of BudgIT involves fact-finding, lobbying, litigation and demand for transparency and accountability of public finance.

v. Their actions are considered legitimate in Nigeria because they represent a collective voice of the masses.

\section{Accountability Framework}

How Can Charity Institutions be Accountable?

To explore the first aspect of reporting behaviour, that is, 'how can they be accountable' or what available mechanisms can the charity entities utilise to be accountable to the demands of stakeholders, Ebrahim (2003a, 2010) suggested charitable institutions can use several ways for reportingsuch as 'annual reports/disclosure', 'evaluation/performance assessment', 'participations', 'self-regulation' and 'adaptive learning'. The use of each of these tools/processes determines either upward, downward or internal accountability. Firstly, accountability through 'annual reports/disclosure' denotes upward accountability because they are regularly required by donors and regulatory bodies/government, must be prepared in 
accordance withthe stipulation and their lack of disclosure attracts sanctions such as fines, withdrawal of funding and losing their non-profit tax-exempt status. The bulk of information in the annual reports/disclosure reports basic financial data with limited disclosure of the quality of work and no attention to clients of the NGO (Ebrahim, 2003a, 2003b).

Secondly, reporting 'evaluation and performance assessment' indicate multidimensional accountability (both upward, downward and internal) depending on the issues under evaluation, the parties involved in the evaluations and to whom the report of the evaluation and assessment finally go. But in most evidence, performance assessment depicts upward accountability (Ebrahim, 2005) because, in the end, results are emphasised,and funders and NGOs use such results for funding purpose (Ebrahim, 2010). For instance, donors may need performance assessment reports near the end of a project/programmes (activities/output)to know the extent of the implementation of the project/programmes (Ebrahim, 2005),e.g. how many housing units built or training programmes on sanitation, trees planted, etc. This report is short-term oriented and focuses on the immediatetangible result. It could be crucial to future funding (Ebrahim, 2005), hence denoting upward accountability.

Thirdly, 'self-regulation' mechanism refers to in-house developed codes and standards by NGOs (Ebrahim, 2003b; Lloyd \& Casas, 2006). They are self-policing voluntary standards and codes of conduct developed by NGOs on primarily internal governance, finance and organisational integrityto redeem confidence on NGOs due to public scandals and in some cases to prevent potential government regulation (Ebrahim, 2003a, 2003b, 2010; Lloyd, 2005; Lloyd \& Casas, 2006).This mechanismskews towards internal accountability and upward accountability. The latter accountability meaning to show donors of "good housekeeping" and avoid intrusive government regulation (Ebrahim, 2003b).

'Participation' and 'adaptive learning' are primarily indicators of downward accountability. For 'participation', charitable entities show transparency, sincerity and try to learn from the beneficiaries by seeking their input on projects and programmes via public meetings, the involvement of client in project implementation, surveys, and formal dialogue (Osman, 2012). While 'adaptive learning' connotes systematic critical reflection and encoding inferences by NGOs in order to actualise their mission. Such reflection provides the opportunity to discuss mistakes by staff, forums for sharing of information with beneficiaries, experimentation, debate and capacity building (Ebrahim, 2010). It is very effective as it is an informal one-on-one dialogue which provides the opportunity to understand the beneficiaries' concerns and needs (Osman, 2012). Adaptive learning generates knowledge and using such knowledge to influence organisational practices (Ebrahim, 2005). Hence, adaptive learning by default connotes both downward and internal accountability.

To whom are Charity Institutions Accountable?

To determine 'to whom they are accountable, the utilisation of the 'how' (Annual report, Evaluation report, Self-regulation, Participation and adaptive learning) mechanisms will primarily point to either upward or downward accountability. For instance, annual report and evaluation report mechanisms mainly symbolise upward accountability, while 'self-regulation' denotes internal accountability and lastly 'participation' and 'adaptive learning' primarily signifies downward accountability. 
For What Purpose is Charity Entities Accountable?

The last aspect of reporting behaviour is 'for what purposes' do charities provide their report to the public. According to Ebrahim (2010:8), the purposes (for what) of charitable institutions means "to be accountable for different things by different people". Ebrahim (2010) submitted that charity organisations' reports are for four reasons; 'finance', 'performance', 'governance' and 'mission'. The first type of purpose focuses on 'finance' which translates to disclosure on financial transactions, conformity to accounting standards/reporting requirement and account for resource use by NGOs (Ebrahim, 2003a). Accountability in this context is strict, rigorous and enforced on NGOs, and if non-complied with, NGOs will be sanctioned with fines, imprisonment, withdrawal of finance, tarnishing of image or loss of tax-exempt status (Ebrahim, 2003b, 2010). Thus, accountability for finance depicts upward accountability.

Accountability for 'performance' relates to the results of the programmes/projects of the charity organisations. This accountability measures the performance of charity organisations and links NGOs goals and objectives to immediate outcome/output (Ebrahim, 2005). As stated by (Ebrahim, 2005, 2010), such accountability is primarily encouraged by donors and the stress on short-term results portray such a purpose as hierarchical accountability. Being accountable for 'governance' focuses on the role of the charity's board of directors. The fiduciary duties of the board of directors centres on serving the mission of the NGOs, financial oversight (how the institution raises and spend money), follows donor intent and to ensure compliance to legal and regulatory laws. Again, this kind of accountability shows conformity to the demands of stakeholders who fund and regulate the charitable sector.

The last type of expectation centres on the charitable organisation's 'mission'. What charity organisations are required to do in this aspect is to report and demonstrate the progress of their programmes and projects towards achieving the sole aim of their creation. As stated earlier, NGOs are accountable to not only upward, downward parties but also internally to their missions, boards and staff (Ebrahim, 2004, 2005, 2010). Hence reporting of mission embraces monitoring results or outcomes by NGOs against their sole existence. Ebrahim asserts that "the mission statement for NGOs provide a focal point around which to develop internal accountability" (Ebrahim, 2003b: 9), thus depicting internal accountability. However, donors study the missions in selecting which NGOs to fund. Thus, reporting this 'what' of accountability may depict both internal and upward accountability, but the former is the primary target.

\section{Data Source}

For the data source for the content analysis, the website, annual reports (2013-2017), voluntary publications and any related news of BudgIT will be examined. 
Table 1. The Accounting Mechanism

\begin{tabular}{|c|c|c|c|c|}
\hline $\begin{array}{l}\text { NGO } \\
\text { Type }\end{array}$ & Orientation & $\begin{array}{c}\text { Accountability } \\
\text { how? } \\
\text { (Tools or process) }\end{array}$ & $\begin{array}{c}\text { Accountability to whom? } \\
\text { (upward, downward, } \\
\text { internal) }\end{array}$ & $\begin{array}{l}\text { Accountability for what? } \\
\text { (finance, performance, } \\
\text { governance, mission) }\end{array}$ \\
\hline \multirow{5}{*}{ 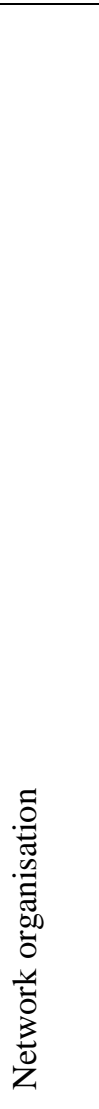 } & \multirow{5}{*}{ 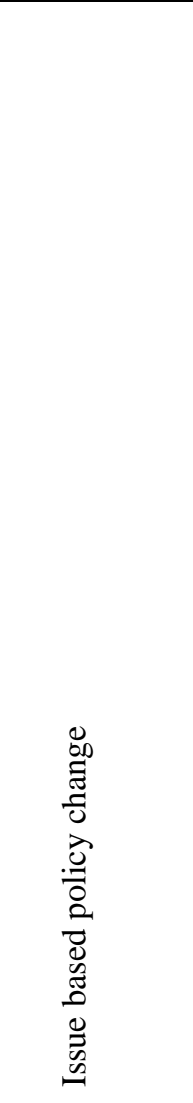 } & $\begin{array}{l}\text { Disclosures/report } \\
\text { (tool) }\end{array}$ & $\begin{array}{l}\text { Primarily } \\
\text { funders } \\
\text { oversight } \\
\text { agencies }\end{array}$ & $\begin{array}{l}\text { - Finance and } \\
\text { performance } \\
\text { depending on what is } \\
\text { being reported }\end{array}$ \\
\hline & & $\begin{array}{l}\text { Evaluation and } \\
\text { performance } \\
\text { assessment (tool) }\end{array}$ & $\begin{array}{ll}\text { - } & \text { Primarily } \\
& \text { funders }\end{array}$ & $\begin{array}{l}\text { - Performance often } \\
\text { short-term output but } \\
\text { with increasing } \\
\text { emphasis on impact }\end{array}$ \\
\hline & & $\begin{array}{l}\text { Self-regulation } \\
\text { (tool \& process) }\end{array}$ & $\begin{array}{l}\text { - To non-profits } \\
\text { themselves as a } \\
\text { sector } \\
\text { To donors as a } \\
\text { seal of good } \\
\text { housekeeping }\end{array}$ & $\begin{array}{l}\text { Finance and } \\
\text { governance } \\
\text { depending on what } \\
\text { the codes or standard } \\
\text { emphasise }\end{array}$ \\
\hline & & $\begin{array}{l}\text { Participation } \\
\text { (process) }\end{array}$ & 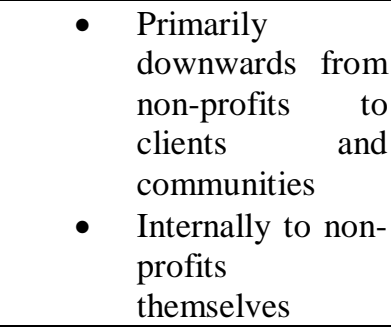 & $\begin{array}{l}\text { - Depends on the } \\
\text { purpose of } \\
\text { participation e.g. } \\
\text { whether to seek input } \\
\text { on implementation } \\
\text { (performance) or to } \\
\text { influence agendas }\end{array}$ \\
\hline & & $\begin{array}{l}\text { Adaptive learning } \\
\text { (process) }\end{array}$ & $\begin{array}{ll}\text { - } & \text { To non-profits } \\
\text { themselves } & \\
\text { - } & \text { Downwards and } \\
\text { upwards r to } \\
\text { stakeholders }\end{array}$ & $\begin{array}{l}\text { - Mission } \\
\text { performance }\end{array}$ \\
\hline
\end{tabular}

Adapted from: Ebrahim (2003a, 2003b, 2010)

\section{RESULT AND DISCUSSION}

In terms of the format of this section, the content analysis of BudgIT's websites, latest annual report, publications and any related news is presented under the following sections: accountability how; accountable to whom; and accountability for what purpose.

How Can Budget be Accountable?

As an advocacy organisation of fiscal transparency, content analysis of BudgIT's websites and relevant news are mostly data on budget information and fiscal analysis of Federal and State Governments, Ministries, Department and Agencies. The timeframe of information on budget and fiscal analysis available for download from BudgIT's website went as far back as 1999 even though the company was established in 2011. Published documents that can be found in the website includeannual reports, performance evaluation reports, public finance documents (budgets), fiscal analysis and surveys.

Firstly, their annual reports from 2013 to 2017 (the latest) are publicly available for download from the website. This finding is expected as there is a law that mandates registered 
charity organisations in Nigeria to submit annual returns each year (see Section 370 \& 690 of CAMA). Another interpretation is that the publication of the five (5) year's annual reports suggests that BudgIT recognised the annual report as a crucial document in their discharge of accountability. This conclusion is consistent with existing studies that the annual report has become the most used tool for reporting by charity organisations (Connolly \& Hyndman, 2004, 2013; Dellaportas, Langton, \& West, 2012; Dhanani \& Connolly, 2012). The average number of pages of the annual reports (2013-2017) is 30 pages and on averaged comprised a higher page count of narrative disclosures on programmes and projects being executed by BudgIT as compared with financial information. For instance, the 2016 and 2017 annual report with 34 and 42 pages respectively, have only three pages of financial information. This suggests that BudgIT recognised the need for non-financial information in discharging their accountability and have understood that financial information is likely more difficult to understand by stakeholders. This finding is consistent with the findings of Connolly \& Hyndman (2013) and (Dhanani \& Connolly (2012) where non-financial information dominated the annual reports.

Similarly, the content of the non-financial information of the annual reports were usually structured under themes such as 'Lead partner's/Trustee's report' 'budget access', 'tracking government projects', 'partnership/workshops/engagement with stakeholders', 'fiscal data analysis and presentations' and 'campaign on national needs'. The reporting of the programmes and projects in the annual reports contained colourful visualisation features in the form of pictures, info-graphs and chain analysis. The colourful pictures generally comprised of images of BudgIT's stakeholders such as the employees/volunteers, donors, beneficiaries/communities, NGOs and government officials.

Performance evaluation reports of BudgIT were reported via a document called 'impact' report. The report reveals the performance of programmes and projects implemented by BudgIT and the overall impact felt by the communities/beneficiaries/clients. Visual colourful images and statistical info-graphs of beneficiaries/communities were also used as a medium to report on the programmes and projects in the 'impact' report. Most information disclosed in the 'impact' report only reported performance information on input (e.g. staff, money and data) and output (e.g. number of citizens having access to fiscal data) without reporting the results (e.g. public officials became prudent and transparent) of programmes and projects, while little information reported all three (3) performance information. In the case of the former, for instance, BudgIT's project on "Visualising education budget for citizen engagement and institutional action", the following 'impact' report was stated:

"Within two months of rollout, citizens had access to at least 40 viral infographics on the state of education and accompanying interactive solutions, which enabled them understand that data is essential to initiating and sustaining robust discussions on the performance of education budgets. BudgIT reached over 600,000 citizens, who are now raising their voices and asking pertinent questions" (Impact report, 2016).

While in the case of the latter, the following 'impact' report was disclosed on the project 'Fix our oil" campaign which translates to a call for more disclosure of Nigeria National Petroleum Corporation's (NNPC) operations in the country: 
"The Fix Our Oil campaign has been tremendous in terms of reach; BudgIT has been able to engage the heads of the NNPC in a series of presentations, as well as with the head of NEITI, Mr. Waziri Adio. The most recent results of these efforts being the joint publication of "One Year of NNPC Reports," with BudgIT on its part reaching at least 400, 000 people within its offline and online communities" (Impact report, 2017).

From the 2016 'impact' report, it could be seen that only the input ("Within two months of rollout") and output ("citizen had access to 40 viral infographics and BudgIT reached over 600,000 citizens") of the project were reported without reporting the results (for instance, transparency and performance of education budgets has increased due to citizens asking questions). However, the 2017 'impact' report did not only disclose the input and output ("engage the heads of NNPC and NEITI"), but also the result (joint publication of "One Year of NNPC Reports") of the "fix our oil" projects. The 2016 performance report fell short of the information needs for stakeholders especially donors because the study by Connolly \& Hyndman (2013) revealed that donors emphasise all performance (input, output and result) information.

Another important published document is the 'Tracka' report. 'Tracka' is a medium created by BudgIT in 2014 to give the Nigerian masses the opportunity to track and report the level of implementation of public infrastructure which at the end of a period is compiled into a report to reveal the level of ongoing construction of infrastructures financed by governments'budget. Visual colourful images of communities, volunteers, infrastructures and beneficiaries are also used for presentational purpose in the 'Tracka' reports.

Other published documents are related to public finance analysis and surveys in the form of info-graphs and other technology-driven statistics. The public finance analysis reports (e.g. Federal, States and MDAs' budget, budgetperformance of Federal, States and MDAs 'Ebola Health Fund Watch' etc.) and surveys (EBOLA Primary Health Care System Survey,). Unlike the annual reports, these published documents are variable in length, lack common themes and inclusive of financial and qualitative information. However, like the annual and impact reports, colourful visual presentations were used in the form of pictures of donors, clients, employees, infrastructure and communities.

Overall, all the information/published documents disclosed point to upward reporting. For instance, the published annual reports primarily reveal how donors' funds were utilised for the advocacy projects. While most performance evaluation reports disclosed via the 'impact' reports disclosed only the performance of the projects with an emphasis on short-term impact. Emphasis on immediate tangible result according to Ebrahim (2003a, 2005) and Jacobs \& Wilford (2010) means reporting of the immediate impact of projects by disclosing the input and output of projects. Most of the performance information published by BudgIT via the 'impact' report disclosed only the input and output of programmes and projects thereby denoting upward accountability. Although the Tracka project reported via the Tracka report has the characteristics of 'participation' mechanism which suggests downward reporting, a closer examination of the project reveals otherwise because in reality the Nigerian masses/beneficiaries are only actors who are being directed by BudgIT to report public finances. The Nigerian masses/beneficiaries do not have a role or input in the structure and how the 'Tracka' project should be executed thereby 
indicating upward accountability. In a nutshell, BudgIT's practices upward accountability to individual donors and policy advocacy networks with whom they share the same cause.

Accountable to Whom

To determine 'to whom they are accountable', the utilisation of the 'how' ('annual report', 'evaluation report', 'self-regulation', 'participation' and 'adaptive learning') mechanisms will primarily point to either upward, downward or internal accountability. In the case of BudgIT, annual, 'Impact' (performance) and 'Tracka' reports symbolise upward accountability. Other documents and information in their website report only the advocacy issues they stand for which is transparency and accountability in budget preparation and implementation. Accordingly, BudgIT's 'accountability to whom' behaviour represents hierarchical reporting.

Accountable For What Purpose

For this analysis, that is 'for what purposes' BudgIT disclose their information, the information disclosed by BudgIT's annual reports (2013-2017) and other information in the website can be categorised into the following themes:

1. Mission, objectives and activities

2. Achievements and performance

3. Financial review

4. Plans for the future

5. Structure, governance and management

6. Reference and administrative details.

Disclosure of theme 1 (Mission, objectives and activities) by BudgIT depicts why the organisation was established and what it intends to achieve. The purpose of disclosure of this information is to report and demonstrate the progress of their programmes and projects towards achieving the sole aim of their creation. Such information as stated by Ebrahim (2003b, 2004, $2005,2010)$ is accountability for 'mission' and reporting of 'mission' embraces monitoring results or outcomes by BudgIT themselves against their sole existence, thus depicting internal accountability. However, donors study the missions in selecting which NGOs to fund. Consequently, reporting this 'what' of accountability by BudgIT depicts both internal and upward accountability.

Reporting of theme 2 (Achievements and performance) can be grouped under the purpose of 'performance' because it is related to results of the programmes/projects of BudgIT. BudgIT reported this theme as it tries to link its goals and objectives to immediate outcome/output of their activities. This kind of accountability as argued by Ebrahim (2003a) is principally encouraged by donors and the stress on short-term results depicts such purpose as upward accountability. The purpose of reporting theme 3 (financial review) which is only available in the annual reports, translates to disclosure on financial transactions and account for resource use by BudgIT. The reporting of such information is a must as stated by Ebrahim (2010) and if non-complied with, donors and partners of BudgIT might withdraw their donations and even lose their tax-exempt status (Osman, 2012). Hence, the reporting of such information connotes hierarchical accountability. 
Finally, the reporting of themes 4 (plans for the future), 5 (structure, governance and management) and 6 (reference and administrative details) focused on being accountable for 'governance'. The purpose of reporting these themes by BudgIT is to show the structure and fiduciary role of the board of directors and staffs in achieving their missions (Ebrahim, 2003a, 2003b, 2010). Conclusively, the analysis of these themes signifies a strong adherence to hierarchical reporting. Overall, the purpose of reporting by BudgIT is mostly to satisfy their donors' information needs and abide by regulations with little consideration to their employees and volunteers.

\section{CONCLUSION}

The Nigerian charity sector plays a major role in social welfare development and activist for social change and accountability is viewed as a very important factor for the prosperity and confidence in the sector. The main objective of this study is to examine the reporting behaviour of charitable organisations in Nigeria. The motivation for carrying out the study lies in determining to whomcharitable organisations are accountable. Previous studies have revealed charitable organisations are accountable to stakeholders who provide funds and regulate charitable organisations. However, empirical evidence from Nigeria is lacking, thus the need for this research.

In achieving the objective of the paper, the famous NGO accountability mechanism developed by Ebrahim (2003a, 2003b, 2010) was employed to examine BudgIT's websites, publications and any related news. The results from the analysis of data showed the reporting behaviour of BudgIT is oriented towards upward accountability even though it was found that internal accountability was insignificantly practised via reporting of their mission and objectives. The findings have corroborated the ten-year study by Edun on NGO's projects in Nigeria that "most projects can be said to have been based on donor-identified needs', rather than on a process of dialogue with the intended beneficiaries and other community stakeholders" (Edun, 2000:48) which underscores the likelihood of upward accountability to donors. Similarly, the findings do not differ from previous studies which found that the accountability of charitable organisations is skewed towards donors and regulators. On a practical level, the most likely reason for practising upward accounting by BudgIT might be attributed to formal external reporting laws by donors and regulators.

Drawing on Edun (2000) and Ebrahim (2003b, 2005), more attention needs to be given to charitable adaptive learning and participation from beneficiaries so that BudgIT will not continue to spend significant resources which will have little or no impact on the intended beneficiaries or advocating for causes that might not be patronised because they do not reflect the real needs of the beneficiaries. The significant contribution of this study is addressing the scarcity of existing literature on accounting and accountability of charitable organisations in Nigeria. To the best knowledge of the researcher, the only known study on accountability of charitable organisation in Nigeria is the study by Edun (2000). By providing evidence on the reporting behaviour of BudgIT in Nigeria, the present study makes a noteworthy contribution to the literature, considering that previous studies have focused on countries, mostly in Europe, the United States of America and Asia. Evidence from a developing African country is lacking. Additionally, unlike most previous studies which tend to focus on the 'service delivery' of NGOs as their case 
studies, this study reports the unique accountability behaviour of a 'network issue-based organisation' (Ebrahim, 2003b).

Inevitably, there are several limitations to the study. First, only a single charitable organisation was examined. Hence, the findings cannot be generalised to other charitable institutions. In addition, the method of data collection employed in this study has inherent shortcomings. Using content analysissomewhat depends on the decision and interpretation of the researcherto determine the reporting behaviour of BudgIT introduces the possibility of subjective interpretation.Having identified the limitations encountered in the study, future research can contribute in several ways to the accounting and accountability of NGOs in Nigeria. First, future studies should study other charitable organisations in the country to determine their reporting behaviour. Similarly, researchers could employ other methods of data collection such as interviews which might provide an in-depth, comprehensive response on the reporting behaviour of charitable organisations in the country.Future research could also explore the accountability of the charity sector after the passage of the proposed 'NGOs' Regulation and Coordination bill 2015 ' to see if such new statutory provisions will enhance sector accountability to all stakeholders.

\section{REFERENCES}

Andrews, A. (2014). Downward Accountability in Unequal Alliances: Explaining NGO Responses to Zapatista Demands. World Development, 54, 99-113. https://doi.org/10.1016/j.worlddev.2013.07.009

Asien, A. A. (2016). Accountability Framework for Not-for-Profit Organisations. The Nigerian Accountant, 49(4), 20-24. Retrieved from http://icanig.org/ican/documents/TNA-oct-dec2016.pdf

Baur, D., \& Schmitz, H. P. (2012). Corporations and NGOs : When Accountability Leads to Cooptation. Journal of Business Ethics, 106, 9-21. https://doi.org/10.1007/s10551-011-1057-9

Bawole, J. N., \& Langnel, Z. (2016). Downward accountability of NGOs in community project planning in Ghana. Development in Practice, 26(7), 920-932.

Beattie, K. (2011). Whose accountability: A case study of NGO accountability to recipient of aid in South Sudan. United Kingdom: Unpublished MSc Research, Cranfield University.

Bradely, M. T. (2005). Civil society and democratic progression in post-colonial Nigeria: The role of non-governmental organisation. Journal of Civil Society, 1(1), 61-74.

Burger, R., \& Seabe, D. (2014). NGO accountability in Africa. In Civil Society in Africa (pp. 77 91). New York, NY: Springer.

Collison, D., Bebbington, J., \& Gray, R. (2006). NGOs, civil society and accountability: making the people accountable to capital. Accounting, Auditing \& Accountability Journal, 19(3), 319-348. https://doi.org/10.1108/09513570610670325

Connolly, C., \& Hyndman, N. (2004). Performance reporting: a comparative study of British and Irish charities. The British Accounting Review, 36(2), 127-154.

Connolly, C., \& Hyndman, N. (2013). Charity accountability in the UK: through the eyes of the 
donor. Qualitative Research in Accounting \& Management, 10(3/4), 259-278.

Davis, D., Jegede, A., Leurs, R., Sunmola, A., \& Ukiwo, U. (2011). Comparing Religious and secular NGOs in Nigeria: Are Faith-based organisations distinctive?Religions \& Development working paper 56.

Dellaportas, S., Langton, J., \& West, B. (2012). Governance and accountability in Australian charitable organisations: Perceptions from CFOs. International Journal of Accounting and Information Management, 20(3), 238-254.

Dhanani, A., \& Connolly, C. (2012). Discharging not-for-profit accountability: UK charities and public discourse. Accounting, Auditing \& Accountability Journal, 25(7), 1140-1169.

Dunne, T. (2013). Governance and performance reporting in Scottish charities. Journal of Financial Reporting and Accounting, 11(2), 112-130. https://doi.org/10.1108/JFRA-112011-0015

Ebrahim, A. (2003a). Accountability in practice: Mechanisms for NGOs. World Development, $31(5), 813-829$.

Ebrahim, A. (2003b). Making sense of accountability: Conceptual perspectives for Northern and Southern nonprofits. Non-Profit Management and Leadership, 14(2), 191-212.

Ebrahim, A. (2004). Seeking NGO-Donor Partnership for Greater Effectiveness and Accountability. Washington, D.C., United States.

Ebrahim, A. (2005). Accountability myopia: Losing sight of organizational learning. Nonprofit and Voluntary Sector Quarterly, 34(1), 56-87.

Ebrahim, A. (2010). The Many Faces of Non-profit Accountability (3rd ed.). Jossey-Bass Handbook of Non-profit Leadership and Management.

Edun, A. (2000). The Role of Evaluation in Accountability in Donor- Funded Projects. IDS Bulletin, 31(1), 48-52.

Essia, U., \& Yearoo, A. (2009). Strengthening civil society organizations/government partnership in Nigeria. International NGO Journal, 4(9), 368-374.

Fasakin, A. (2011). Non-governmental organisations and civil corruption in Nigeria's public space. In Proceedings of theInternational Conference on Corruption, Governance and Development in Nigeria. Aminu Kano Centre for Democratic Research and Training in conjunction with UNECA and the UNDP.

Goddard, A., \& Assad, M. J. (2006). Accounting and navigating legitimacy in NGO's. Accounting, Auditing \& Accountability Journal, 19(3), 377-404. https://doi.org/10.1108/09513570610670343

Hooper, K., Sinclair, R., Hui, D., \& Mataira, K. (2007). Financial reporting by New Zealand charities: finding a way forward. Managerial Auditing Journal, 23(1), 68-83. https://doi.org/10.1108/02686900810838173

Ibeanu, O. (2009). Baseline survey of civil society organisation in Nigeria. Dakar: OSIWA and CODESRIA.

Iheme, E. (2001). Country report for Nigeria NGO laws and regulations. Retrieved May 5, 2018 , 
from https://www.cof.org/sites/default/files/documents/files/International Reporter NIGERIA.pdf

Jacobs, A., \& Wilford, R. (2010). Listen first: a pilot system for managing downward accountability in NGOs. Development in Practice, 20(7), 797-811.

Kaldor, M. (2003). Civil Society and Accountability. Journal of Human Development: A MultiDisciplinary Journal for People-Centered Development, 4(1), 5-27. https://doi.org/10.1080/1464988032000051469

Keystone. (2006). Survey Results : Downward accountability to 'beneficiaries ': NGO and donor perspectives. System.

Lloyd, R. (2005). The role of NGO self-regulation in increasing stakeholder accountability. $\begin{array}{llll}\text { Retrieved } \quad \text { May 20, 2017, from } & \text { 20 }\end{array}$ http://coddeconduitaong.ro/wordpress/wpcontent/uploads/2011/08/The_Role_of_NGO_Sel f Regulation_in_Increasing_Stakeholder_-Accountability.pdf

Lloyd, R., \& Casas, L. de las. (2006). NGO self-regulation: enforcing and balancing accountability. Retrieved from www.oneworldtrust.org

Nwokoro, C., V. (2017). Assessing the distinctiveness of Faith-based organisation in the development sector in Nigeria. Journal of Humanities and Social Policy, 3(2), 1-16.

O'Dwyer, B. (2005). The construction of a social account: a case study in an overseas aid agency. Accounting, Organizations and Society, 30(3), 279-296.

O'Dwyer, B., \& Boomsma, R. (2015). The co-construction of NGO accountability: Aligning imposed and felt accountability in NGO-funder accountability relationships. Accounting, Auditing \& Accountability Journal, 28(1), 36-68.

O’Dwyer, B., \& Unerman, J. (2007). From functional to social accountability. Accounting, Auditing \& Accountability Journal, 20(3), 446-471.

O'Dwyer, B., \& Unerman, J. (2008). The paradox of greater NGO accountability: A case study of Amnesty Ireland. Accounting, Organizations and Society, 33(7-8), 801-824.

Odumosu, O., Olaniyi, R., \& Alonge, S. (2009). Mapping the activities of Faith-based organisation in develoment of Nigeria (Religions and Development Research Programme No. Working Paper 38). Retrieved from https://core.ac.uk/download/pdf/8771863.pdf

Osman, A. Z. (2012). Accountability in managing waqf properties: the case of two State Religious Councils in Malaysia.

Republic of Nigeria. Companies and Allied Matters Act (CAMA) (1990).

Unerman, J., \& O'Dwyer, B. (2006). Theorising accountability for NGO advocacy. Accounting, Auditing \& Accountability Journal, 19(3), 349-376. https://doi.org/10.1108/09513570610670334

Yasmin, S., Haniffa, R., \& Hudaib, M. (2014). Communicated Accountability by Faith-Based Charity Organisations. Journal of Business Ethics, 122(1), 103-123. https://doi.org/10.1007/s10551-013-1759-2 